\title{
ORIGIN AND DEFINITION OF THE CATEGORY OF ECONOMIC SECURITY OF ENTERPRISE
}

\author{
Alina Ianioglo ${ }^{1}$, Tatjana Polajeva ${ }^{2}$ \\ ${ }^{1}$ Faculty of Economics, Comrat State University, Galatsan str. 17, Comrat, Republic of Moldova \\ ${ }^{1,2}$ School of Economics and Business Administration, Tallinn University of Technology, \\ Ehitajate tee 5, Tallinn, Estonia \\ E-mails: ${ }^{1}$ alina.ianioglo@gmail.com (correspondingauthor); ${ }^{2}$ tatjana.polajeva@ttu.ee
}

\begin{abstract}
This article aims to reveal the essence of the economic security of enterprise, the origin of this concept. This study is necessary due to the difference of interpretations of the economic security. By analyzing and systemizing results of scientific studies, there can be distinguished five main approaches to its definition. Main threats that affect enterprises are identified and presented. Uncertainty and changeability of external and internal environments, under which enterprises operate, makes the topic relevant. At the present time, economic security of enterprise is an important factor of improving its economic condition and ensuring its sustainable development.
\end{abstract}

Keywords: development, economic security of enterprise, efficiency, hazards, threats, security, sustainability.

JEL Classification: M10; M21; G32.

\section{Introduction}

In modern conditions of an open competitive environment, political and economic instability, economic entities have a full autonomy in making decisions on the development strategy, the organization of production and sales of products, the choice of contractors and other management decisions. Entrepreneurs assume the most of the business risks. Under these conditions, problems of viability and ensuring the economic security of enterprises become of a particular importance. Despite the fact that the problems of ensuring economic security of an enterprise in recent years become of a particular relevance, they are not fully studied.

Therefore, the purpose of this article is to study the essence of economic security of enterprise by considering the historical aspect of this issue and analysis of the definition of a number of scientists; as well as the identification of the main threats to economic security.

\section{Security and types of security}

At all stages of economic development enterprises are the main element of the economy. They represent an open dynamic system and operate under the influence of numerous factors, in conditions of environment instability. The statistics of world business shows that $80 \%$ of all newly established businesses cease to exist during the first five years of their activity (Hindle, Klyver 2011). This fact indicates that the achievement of an effective strategic management is a very difficult task.

All the power of an enterprise is based on three elements: profit, development and security. The term "security" has a universal character and firmly entrenched in our lives. In Maslow's hierarchy of needs, safety needs refer to the basic human needs. There are several types of security by content that is, depending on the areas of public life and the direction of human activities, presented in Figure 1.

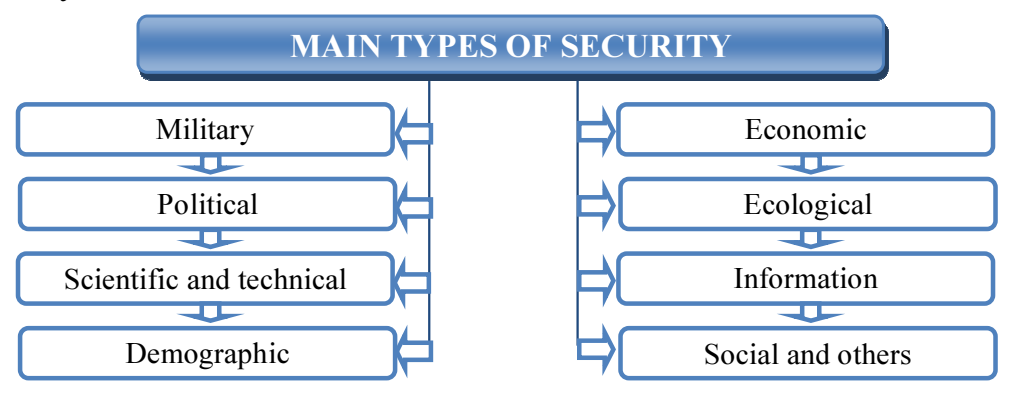

Fig. 1. The main types of security by content (Source: Zaharchenko et al. 2009)

\footnotetext{
(C) 2016 The Authors. Published by VGTU Press. This is an open-access article distributed under the terms of the Creative Commons Attribution License (CC-BY 4.0), which permits unrestricted use, distribution, and reproduction in any medium, provided the original author and source are credited.
} 


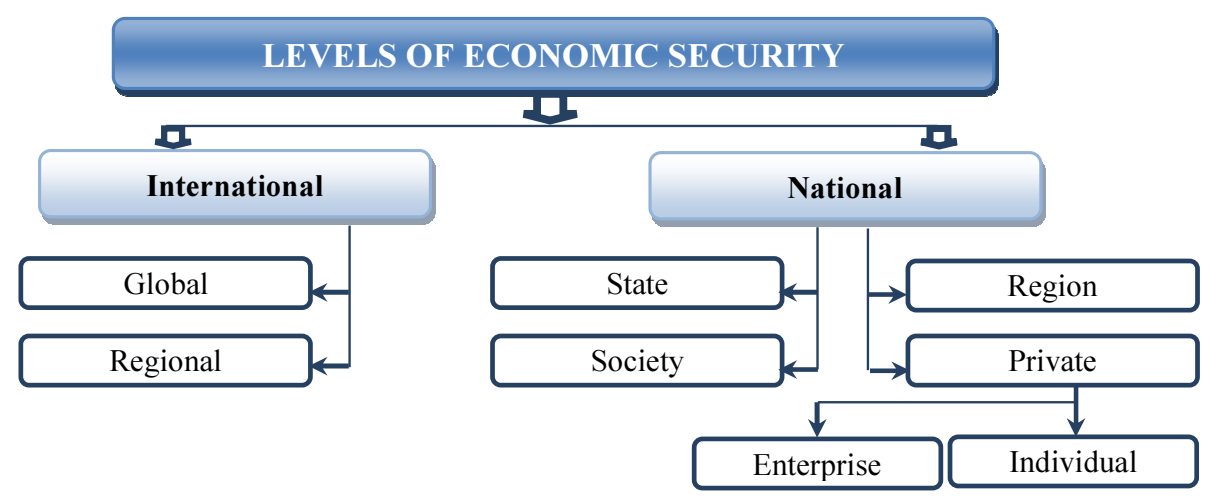

Fig. 2. Levels of economic security (Source: Vechkanov 2007)

Economic security holds a special place among the various types of security. This is due to the fact that all types of security anyway cannot be sufficiently realized without economic aspect. There could be distinguished two groups of the economic security: international and national (Fig. 2).

All decisions taken at higher levels apply to lower levels.

\section{The historical development of the term "economic security"}

Since ancient times, one of the reasons for bringing people into society was the pursuit of security. The scale of needs have constantly increased from security at the individual level to the level of entire society, the whole state.

The first mention of the term "security" refers to $1190^{\text {th }}$ year in the dictionary of English scientistphilosopher Robert, who treated it as a calm state of the human spirit, who considers himself protected from any danger (Goncharenko 2004). Howev$\mathrm{er}$, in this sense, the term was rarely used. In the 17-18 centuries, this concept was used from the position of the state, which was designed to ensure the general welfare and security of citizens.

In the explanatory dictionary of V. Dali, the word "security" cannot be found in its pure form. Nevertheless there is given the adjective "secure", in which description the noun "security" is additionally presented. It is defined as the absence of danger; safety, reliability. Already, S. Ozhegov in his dictionary used the noun "security" itself and defined it as a state in which danger does not threaten, a protection from danger (Ozhegov, Shvedova 2016).

Security, in accordance with the definition proposed by A. Wolfers "in an objective sense, measures the absence of threats to acquired values, in a subjective sense, the absence of fear that such values will be attacked" (Lasan 2010).
Thus, the concept of security according to the etymology of this word means lack of danger, that is, i.e. security is a state of protection of the vital interests of economic entities from internal and external threats. Under vital interests there are implied a complex of needs, which satisfaction promotes "the existence and possibilities of progressive development of an individual, society and state" (Gaponenko et al. 2007). From this it follows that the security is a state, in which the existence and possibility of progressive development are provided.

The term "economic security" began to be used during the "Great Depression" (1929-1933 years). In order to bring the country out of crisis and to restore its economic potential, in 1934 the Committee on Economic Security was established by president's F. Roosevelt decision (Belostecinic et al. 2011). This committee dealt with the economic security of individuals, the fight against unemployment. The term "economic security" got an official status in 1985, when at the 40th session of the General Assembly of the United Nations the resolution on international economic security was adopted.

Until recently, economic security was considered predominantly by western scientists. In postSoviet countries, deep economic crisis of ' 90 s of $\mathrm{XX}$ century has generated many unforeseen dangers and threats to nascent businesses. In conditions of socio-economic reforms of those years there appeared a need to study the issues of ensuring economic security. One of the first soviet scientists, who introduced the economic security issue in modern economics, was academician L. Abalkin. According to his definition, economic security is a state of an economic system, which allows it to develop dynamically, efficiently, and to solve social problems, and in which the state has the ability to develop and implement an independent economic policy (Fedorov 2010). 
In Business Dictionary, economic security is defined as "a situation of having a stable source of financial income that allows for the on-going maintenance of one's standard of living currently and in the near future" (Business Dictionary 2016).

An essential part of scientific works, especially western, refer to the security at the state level. In conditions of transition to market relations by postSoviet countries, the issues of economic security at the level of an economic entity acquired greater importance, however, are still not fully studied.

Private economic security (of enterprises and individuals) represent a state of legal, industrial and organizational relations, material and intellectual resources, under which the reliability and stability of functioning, financial and commercial success, progressive scientific, technological and social development are ensured (Zaharchenko et al. 2009).

\section{Approaches to the definition of economic security of enterprise}

By K. Zukrowska opinion "in macroeconomic terms the economic security means job stability, low unemployment, prospects of predictable growth of the economy, characterized by liquidity. In microeconomic terms of the solvency of the home or business. In both cases, it is the ability to balance the obligations in relation to the needs in the medium term" (Raczkowski, Schneider 2013). Author was limited to defining economic security of enterprise only from a position of solvency.
$\mathrm{K}$. Dent mentioned that economic security is a preservation of the structural integrity and generating prosperity opportunities and interests of political and economic entity in the context of various external risks and threats facing them in the international economic system (Soimu 2010). The author spoke about necessity of protection against external threats. At the same time remain unaccounted internal threats, which also have a significant effect on the activity of the entity.

As it was noted by the american economists S. Morreale and D. Lambert, economic security of enterprise is one of the elements of protection the national security (Korchevska 2015). Due to the fact that in official documents there is no clear definition of economic security of enterprise, in economic literature there are various interpretations of this term. By analyzing the conceptual apparatus of "economic security of enterprise", it can be indicated that this concept is considered from several points of view (see Fig. 3).

1. The first approach to the definition of the economic security of enterprise is based on the use of concept of protection from threats. For example, G. Vechkanov noted that under the economic security of the enterprise is understood the protection of its scientific, technological, production and personnel potential from active or passive economic threats. In the definition is determined the impact of the environment on economic security, but there is not mentioned anything about his internal environment (Suglobov et al. 2013).

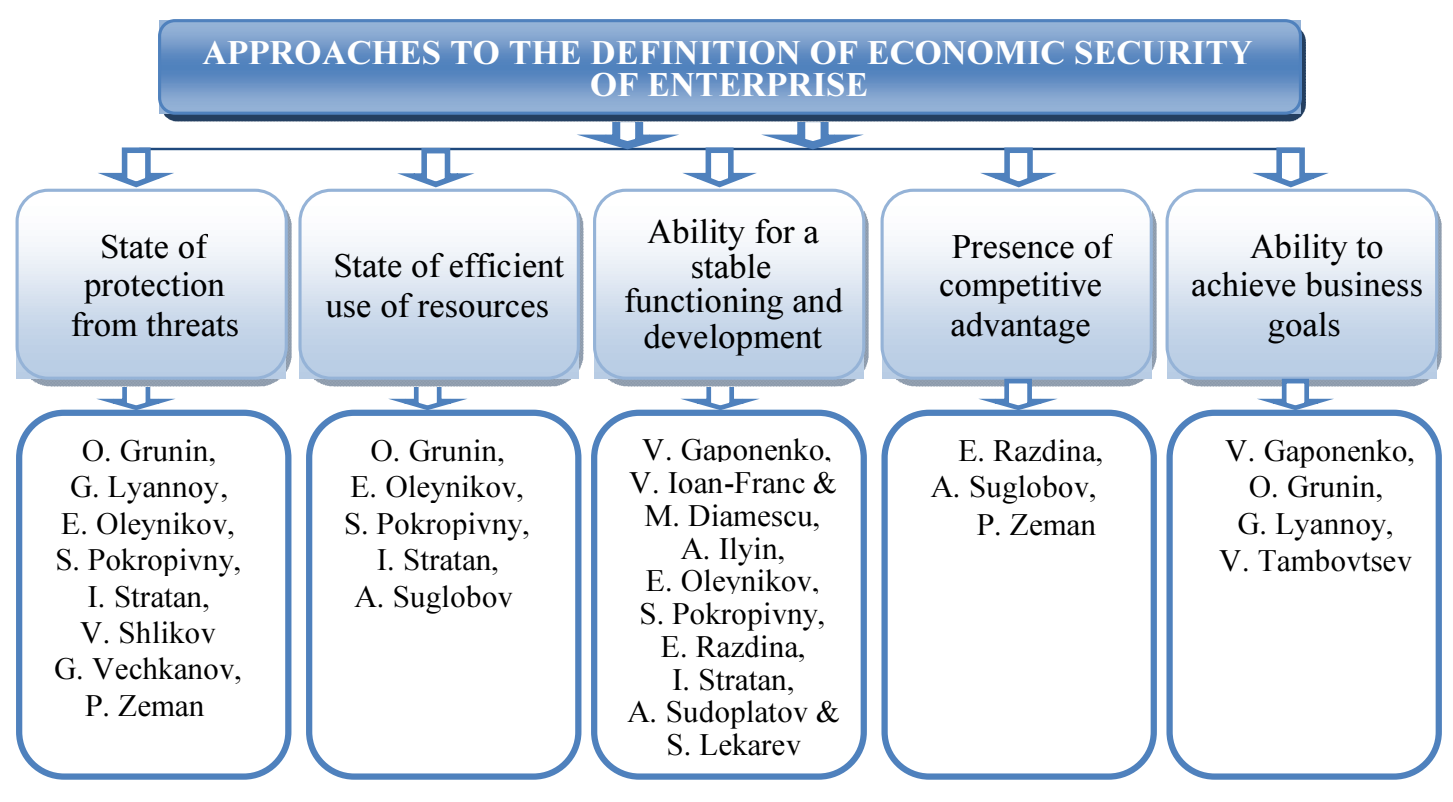

Fig. 3. Approaches to the definition of economic security of enterprise (Source: Ianioglo, Parmacli 2015) 
V. Shlykov (1999) brought the essence of the economic security of enterprise only to protection against threats, defining it as a state of protection of the vital interests of the enterprise from the actual and potential hazards or economic threats. Of particular importance is the search for the optimum ratio between probable losses in cases of violation of the enterprise's interests and allowed cost value to avoid or minimize losses.

2. The second approach, which consists in the fact that the economic security of enterprise is seen as a state of efficient use of resources, is closely related to the first approach. These approaches are often used together in determining the economic security. S. Pokropivny noted that the economic security of enterprise is a state of corporate resources (capital, personnel, information, technology and technique, equipment, rights resources) and business opportunities, in which is guaranteed their the most effective use to ensure stable operation and dynamic scientific, technical and social development, prevention of internal and external negative influences (threats) (Pokropivnyj 2003).

E. Oleynikov (1997) defines economic security as a state of the most effective use of resources to overcome threats and ensure stable operation of the enterprise now and in the future. A similar definition was given by I. Stratan (2007): a state of the most efficient use of all resources in order to prevent (neutralize, eliminate) threats and ensure stable functioning of enterprise in a market economy.

E. Oleynikov (1997) and I. Stratan (2007) used heavily determined indicator "efficient use of resources", at the same time these definitions have a comprehensive nature, as there are discussed multiple processes in the enterprise's activity. E. Oleynikov (1997) distinguished seven functional components as the main areas of economic security of enterprise: financial, intellectual and personnel, technical and technological, political and legal, ecological, information and power. The advantage of this approach of determination the main components of economic security consists in a complex character. However, this advantage is also its disadvantage, because economic security is seen very widely and, in fact, it is identified with the activity of enterprise and its efficiency.

3. According to the third approach, economic security of enterprise is determined by the position of the ability for a stable functioning and development.

V. Ioan-Franc and M. Diamescu (2010) considered that economic security of economic agents provides appropriate conditions for the stability of economic activity during each cycle of production, exchange, distribution and consumption.

The economic security of enterprise represent the neutralization of factors that undermining the stable functioning of the economic mechanism of enterprise. The enterprise's activity should not be limited only at neutralizing factors, as it is noted in the definition, but should ensure a permanent protection.

Authors understood analyzed term as a state of economic, legal and production relations of enterprise, as well as the material, intellectual and information resources that expresses the enterprise's ability to a stable functioning. The focus is based on ensuring the stable operation of an enterprise. However, it is important not only to ensure stability, but also to support enterprise development.

4. According to another approach, the economic security of enterprise is defined as having a competitive advantage. A. Suglobov et al. (2013) believed that economic security is a system that provides competitive advantages of enterprise through the effective use of resources (material, labor, financial, investment) based on the study of comprehensive information formed in the integrated accounting and information system. In the process of ensuring economic security, the author devotes a great importance to the information, which if it is used properly, can provide advantages to enterprise.

5. One of those who examined economic security from the fifth position, achieving the goals is V. Tambovcev (1995). By him, under the economic security of a system is necessary to understand the totality of the properties of the state of its production subsystem that provides the ability to achieve the goals of the entire system. Achieving business goals serves as a criterion of security.

V. Gaponenko et al. (2007) considered the economic security as a state of enterprise, which is characterized by its ability to function properly in order to achieve its goals under the existing external conditions and their change within certain limits. In his definition, V. Gaponenko did not use the term "threat" because he did not recognize the concept of economic security secondary to the concept of threat, disagreeing so with the statement that protection from threats should be carried out only when it will be determined that this threats exist.

If the first approach assumes that the enterprise is economically secure when it is protected from threats, then by the fifth approach, ensuring the economic security represent more difficult task 
of giving the enterprise of such qualities, in which it will be able to achieve business goals. In contrast to the first approach, here the activity of ensuring the economic security shifts from the guard and detective to the analytical and managerial levels.

It can be noted that many authors: O. Grunin (Grunin, O. A., Grunin, S. O. 2002), G. Lyannoj (2006), E. Razdina (1997), P. Zeman et al. (2003) in their definitions of enterprise economic security adhere to a mixed approach. O. Grunin gave the following definition of economic security of enterprise: it is a state of economic entity, in which it by the most efficient use of corporate resources get prevention, reduction or protection against existing hazards and threats, or other unforeseen circumstances and generally ensures achieving business goals in conditions of competition and economic risk (Grunin, O. A., Grunin, S. O. 2002). In this definition, it can be distinguished two main points: firstly, the achievement of business goals as a criterion of security, and secondly, there are taken into account factors of external conditions: competition, economic risk. Also author speaks about the condition for achieving business goals, which is efficient use of resources (Gaponenko et al. 2007).

In accordance with the definition of G. Lyannoj, the analyzed term represent a state of protection from negative influence of external and internal threats, destabilizing factors; under which there are provided sustainable implementation of major commercial interests and goals (Lyannoj 2006).

E. Razdina (1997) gave the following definition: economic security of enterprise is a set of measures that promote the financial stability of economic entities in the market economy and that protect their commercial interests from the negative impact of market processes. This definition focuses on improving the financial stability of the enterprise.

P. Zeman noted that economic security is a state in which the economy of the subject whose security must be provided (enterprise, country, group of countries, world, individual, family, etc.) are not exposed to threats that can significantly reduce its efficiency required for ensuring defense, as well as competitiveness in domestic and foreign markets (Strelcova et al. 2015). The author examines the economic security from the perspective of protection against threats and maintaining the competitiveness of the entity. However, nothing is mentioned about the need to maintain a sustainable development.

By our opinion, economic security of enterprise is a state characterized by the ability of the economic entity to ensure efficient use of resources and opportunities to prevent threats and increase competitive advantages that will allow to ensure stable functioning and development in order to achieve business goals (Ianioglo, Parmacli 2015). The ensuring economic security of enterprise is important for realization of a continuous process of reproduction.

Economic security of enterprise includes three important elements:

- Economic independence.

- Sustainability.

- Development.

Economic independence implies exercising control over its own resources, is the ability to pay timely its obligations. It is necessary to get such level of production that would ensure the company's competitiveness on the market.

Sustainability is understood as a stability of functioning, a financial situation where the fulfillment of all its obligations to employees, other organizations and state are ensured.

Development involves improvement of enterprise performance and bringing it to a satisfactory state. If the enterprise does not develop, does not reach the efficiency, then its ability to adapt to external and internal conditions decreases, and therefore the ability to survive reduces.

\section{Discussions}

Authors consider, that diferent types of the threats influence the economic security of enterprise. Multiple threats may lead to negative consequences in form of solvency and financial stability violations, profitability reduction and other deterioration in the enterprise. This is why it is so important to identify and take into account risks and threats to economic security.

A hazard is defined as "a source of danger that may cause harm to an asset" (Rausand 2011). Threats to economic security of enterprise are potential or actual actions of individuals or entities that may lead to economic or other losses up to bankruptcy of an enterprise. "The concept is closely related to, but differs from, the concept of hazard, which is not directed to exploit vulnerability. A threat is therefore a hazard, but a hazard need not be a threat" (Rausand 2011).

There are many risks, hazards and threats, however, they can be grouped according to various classification criteria. The classification of dangers and threats depending on the source of their origin are the most used. On this basis there are distinguished internal and external threats. In order to maintain their activities, to survive in a competitive 


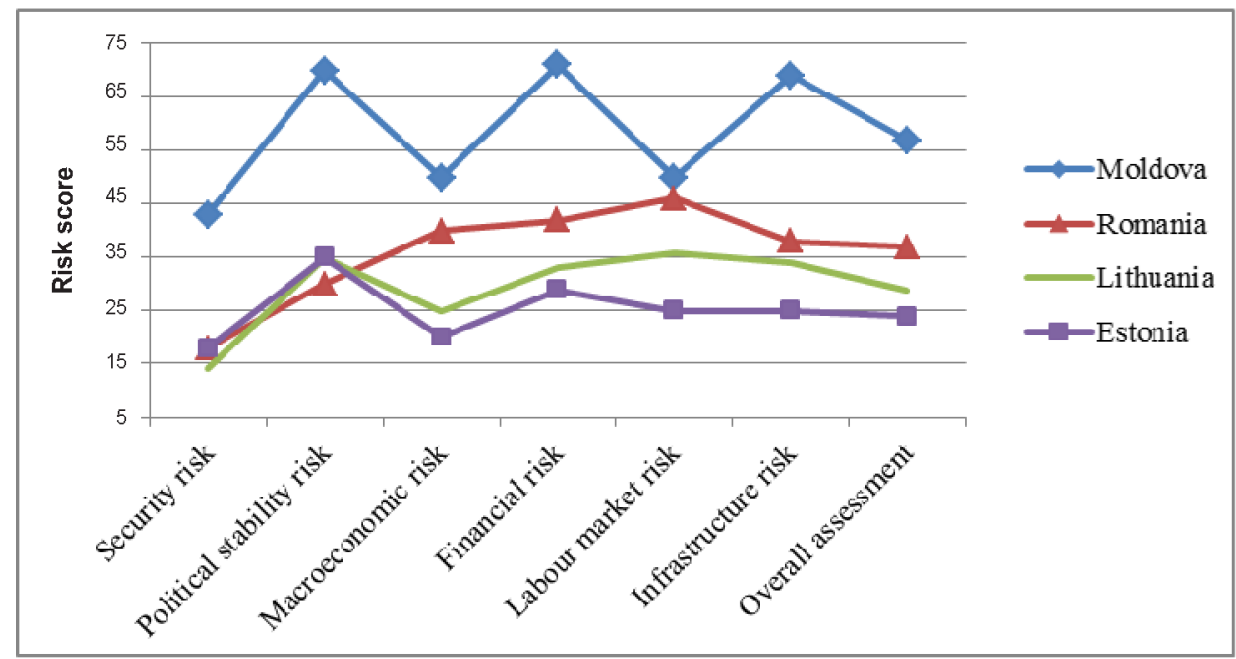

Fig. 4. Risk ratings on constituents for Moldova, Romania, Lithuania and Estonia (Source: compiled by authors based on Economist Intelligence Unit 2015)

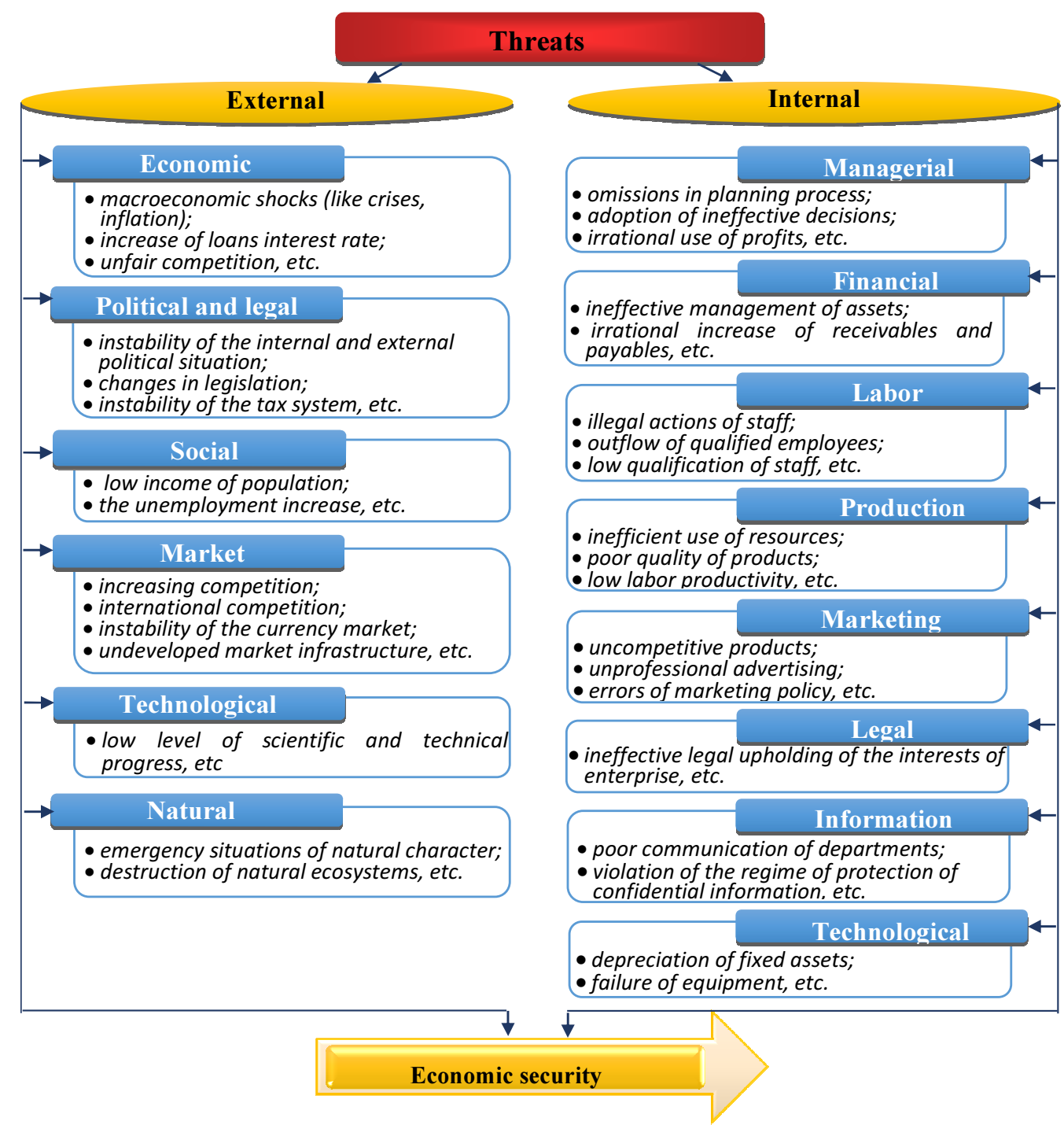

Fig. 5. External and internal threats to the economic security of enterprise (Source: developed by the author based on Vechkanov 2007) 
environment, enterprises should timely respond to changes in the environment, regardless of their positive or negative influence.

External hazards and threats represent changes in the environment that in a certain way may adversely affect the enterprise's activity, its economic security.

In Figure 4 are presented country risks on the seven constituents for Republic of Moldova, Romania, Lithuania and Estonia.

As shown in Figure 4, Republic of Moldova is characterized by the highest risk level, the final score is 57 out of 100 . If to compare this indicator with the Estonian one, we can see that it is 2.4 times higher than in Estonia. At the same time, the financial risk and the risk of political stability are the greatest risks to analyzed countries. It certainly affects the level of economic security of enterprises, which are the main players in the market.

The study of international experience and works of western scientists over the past decade shows that the macroeconomic situation, formed after the crisis of 1974-1975 years, in conditions of transition from the world system of dollar-gold standard to a system of floating exchange rates, is characterized by high instability of financial markets. Domestic enterprises, regardless of their ownership form, are significantly affected by the financial risks due to a lack of experience in managing these risks (Babii 2002). Enterprise is an important component of the economic system and must meet requirements of reality, must change in accordance with the changes in the environment in order to maintain its competitiveness.

Internal hazards and threats are directly related to the economic activities of enterprises, their staff, and have a direct impact on business results.

Possible threats of external and internal nature are presented on Figure 5.

We should not be limited to the listed above threats, since internal and external hazards and threats are individual for each enterprise and depend on the scale of enterprise, branch features and areas of activity. It should be emphasized that the identification of threats is one of the most important tasks of ensuring economic security, because only after the threats will be identified, further measures to neutralize or minimize them can be taken.

\section{Conclusions}

The analyzed topic, the economic security of enterprise is relatively new to modern economic science.
The analysis of the conceptual apparatus of the category "economic security of enterprise" showed that there are five approaches to its definition proposed by different scientists. It can be noted that some authors used a mixed approach.

The economic security of enterprise is affected by both external and internal threats. Most of them are presented in the article. All of them are interrelated.

Today, ensuring economic security of an enterprise, which is based on the three important elements, becomes an important task on different levels. Significant role among the elements is given to the sustainability. It is an important factor in improving economic situation of an enterprise that allows to achieve business goals.

\section{References}

Babii, L. 2002. Riscul financiar si stabilitatea firmei în economia de piata [Financial risk and stability of the company in market economy]. Univ. de Stat „Alecu Russo" din Balți, Chisinau [s.n.] (in Romanian).

Belostecinic, Gr.; Sakovici, V.; Moiseenko, E. 2011. Securitatea economică a statului: teorie, metodologie, practica [The economic security of the state: theory, methodology, practice]. Chisinau: ASEM (in Romanian).

Business Dictionary. 2016. Economic security [online], [cited 4 February 2016]. Available from Internet: http://www.businessdictionary.com/definition/econ omic-security.html

Economist Intelligence Unit. 2015. Risk briefing. Risk scenarios and ratings [online], [cited 19 September 2015]. Available from Internet:

http://viewswire.eiu.com/index.asp?layout=RKCo untryVW3\&country_id $=1680000168$

Fedorov, A. Ju. 2010. Rejderstvo $i$ korporativnyj shantazh (organizacionno - pravovye mery protivodejstviya) [Raiding and corporate blackmail (organizational and legal measures of counteraction)]. Moskva: Volters Kluver (in Russian).

Gaponenko, V. F.; Bespal'ko, A. A.; Vlaskov, A. C. 2007. Jekonomicheskaja bezopasnost' predprijatij. Podhody $i$ principy [Economic security of enterprises. Approaches and principles]. Moskva: Izdatel'stvo Os'-89 (in Russian).

Goncharenko, L. P. 2004. Process obespechenija jekonomicheskoj bezopasnosti predprijatija [The process of ensuring the economic security of the enterprise] Spravochnik jekonomista 12 [online], [cited 24 September 2013]. Available from Internet: http://www.profiz.ru/se/12_04/952/

Grunin, O. A.; Grunin, S. O. 2002. Ekonomicheskaya bezopasnost' organizacii [Economic security of the organization]. Sankt Peterburg: Piter (in Russian). 
Hindle, K.; Klyver, K. 2011. Handbook of research on new venture creation. Chelterham: Edward Elgar Publishing, Incorporated. http://dx.doi.org/10.4337/9780857933065

Ianioglo, A. I.; Parmacli, D. M. 2015. Effektivnost' zemlepol'zovaniya i ehkonomicheskaya bezopasnost' sel'skohozyajstvennyh predpriyatij [Landuse efficiency and economic security of enterprises], Chapter 6, in D. M. Parmacli, et al. Jeffektivnost' zemlepol'zovanija: teorija, metodika, praktika: monografija. Gos. un-t, Nauch.-issled. centr "Progress". Komrat: B. i. (in Russian).

Ioan-Franc, V.; Diamescu, M. A. 2010. Some opinions on the relation between security economy and economic security, Romanian Journal of Economics 31: 129-159.

Korchevska, L. 2015. Periodization of the stages of the formation and development of knowledge about economic security of enterprise, Wspolpraca Europejska/European Cooperation 1(1): 54-65.

Lasan, N. 2010. Securitatea: concepte în societatea contemporană [Security: concepts in contemporary society], Revista de Administrație Publică și Politici Sociale 4(5): 39-50 (in Romanian).

Lyannoj, G. 2006. Ekonomicheskaya bezopasnost' predpriyatiya [Economic security of enterprise], Best of Security. No 7 [online], [cited 1 November 2013]. Available from Internet:

http://www.bos.dn.ua/view_article.php?id_article= 27 (in Russian).

Oleynikov, E. A. 1997. Osnovy jekonomicheskoj bezopasnosti (gosudarstvo, region, predprijatie, lichnost') [Basics of economic security (state, region, company, person)]. Moskva, M: ZAO Biznes-shkola Intel-Sintez (in Russian).

Ozhegov, S. I.; Shvedova, N. I. 2016. Tolkovyj slovar [online], [cited 3 February 2016]. Available from Internet: http://dic.academic.ru/dic.nsf/ogegova/277095/ (in Russian).

Pokropivnyj, S. F. 2003. Ekonomika predpriyatiya [The economics of enterprise]. Kiev: KNEU (in Russian).
Raczkowski, K.; Schneider, S. 2013. The economic security of business transactions. Management in business. Oxford: Chartridge Books Oxford.

Rausand, M. 2011. Risk assessment: theory, methods, and applications. Hoboken: John Wiley \& Sons, Inc., Publication. http://dx.doi.org/10.1002/9781118281116

Razdina, E. 1997. Kommercheskaja informacija i jekonomicheskaja bezopasnost' predprijatija [Commercial information and economic security of the enterprise], Biznes - inform 24: 63-65 (in Russian).

Shlykov, V. V. 1999. Kompleksnoe obespechenie ehkonomicheskoj bezopasnosti predpriyatiya [Integrated ensuring of the economic security of the enterprise]. Sankt Peterburg: Aleteya (in Russian).

Soimu, O. 2010. Security nexus in the light of foreign economic policy, Revista de filozofie, sociologie, şi ştiințe politice 3(154): 170-176.

Stratan, I. 2007. Bezopasnost' biznesa [Business security]. Kishinau: Elan - Poligraf (in Russian).

Strelcova, S.; Rehak, D.; Johnson, D. 2015. Influence of critical infrastructure on enterprise economic security, Communications 1: 105-110.

Suglobov, A. E.; Hmelev, S. A.; Orlova, E. A. 2013. Jekonomicheskaja bezopasnost' predprijatija [The economic security of enterprise]. Moskva: Juniti Dana (in Russian).

Tambovcev, V. L. 1995. Jekonomicheskaja bezopasnost' hozjajstvennyh sistem: struktura, problem [Economic security of economic systems: structure, problems], Vestnik $M G U$ 3: 3-9 (in Russian).

Vechkanov, G. S. 2007. Jekonomicheskaja bezopasnost': uchebnik dlja vuzov [Economic security]. $\mathrm{SPb}$.: Piter (in Russian).

Zaharchenko, V. I.; Merkulov, N. N.; Halikyan, N. V. 2009. Ekonomicheskaya bezopasnost' biznesa [Economic security of business]. Odessa: Nauka i tekhnika (in Russian).

Zeman, P., et al. 2003. Česká bezpečnostní terminologie [Czech Safety and Security Terminology]. $1^{\text {st }}$ ed. Masaryk University, Brno (in Czech). 